\title{
Perception and Extramission in De quantitate animae
}

\author{
Mark Eli Kalderon
}

\begin{abstract}
Augustine is commonly interpreted as endorsing an extramission theory of perception in $D e$ quantitate animae. A close examination of the text shows, instead, that he is committed to its rejection. I end with some remarks about what it takes for an account of perception to be an extramission theory and with a review of the strength of evidence for attributing the extramission theory to Augustine on the basis of his other works.
\end{abstract}

Keywords: Augustine, perception, vision, extramission, De quantitate animae

\section{Augustine and Extramission}

Augustine is commonly interpreted as endorsing an extramission theory of perception.

Extramissive elements can be found in a number of his works (De musica 6.8.21, De Gen. ad lit. 1.16, Sermon 277.10, De Trin. 9.3). However, at least in his early work, De quantitate animae (henceforth, DQA) far from endorsing an extramission theory of perception, Augustine explicitly argues for its rejection. And yet on a common interpretation, Augustine is understood to endorse the extramission theory in DQA. (See, for example, Colleran 1949, 205 n55, 208-10 n73, Gannon 1956, 169 n56, O'Daly 1987, 82-3, Brittain 2002, 276 n64, Silva and Toivanen 2010, 248 n8, Brown 2012, 223-4, Toivanen 2013, 136, Silva 2014, Smith 2015, 154, 266. Nor is this a modern trend, thus Roger Bacon, Perspectiva 1.7.2 commends Augustine's commitment to extramission even as Peter John Olivi, Quaest. in sec. lib. Sent. criticizes it. In addition, Peter Sutton, Quod. 1.24 attributes the extramission theory to Augustine's early works, to which DQA belongs, even though Sutton holds that Augustine later abandons this view.) It is perhaps worth considering Augustine's anti-extramission argument in detail. That argument is a response to a puzzle or aporia that Evodius raises concerning the inextended, and, hence, incorporeal, nature of the soul. According to Evodius, we enjoy tactile sensation when we are touched anywhere on the body. If the soul is not itself extended throughout the body, then how could this be?

We shall begin by discussing the textual evidence for attributing to Augustine an extramission theory in DQA 23. While suggestive, it is, by itself, inconclusive. Context matters if we are to understand Evodius' puzzle and Augustine's reply to it. In the third section, we shall review the project of DQA, in the fourth, we shall discuss Augustine's definition of perception, before turning to the fifth, where we shall discuss Augustine's reply in DQA 30 and explain why this commits him to rejecting the extramission theory. If Augustine explicitly rejects the extramission theory in chapter 30 , then he could not have endorsed it in chapter 23 , on pain of incoherence.

If Augustine in DQA is committed to the rejection of the extramission theory, why is he persistently misunderstood? To address this question, the present essay ends with two sets of reflections. First, I shall provide a diagnosis for the misattribution in terms of unclarity about the commitments of the extramission theory. Specifically, we shall consider what it means to describe an account of perception as extramissive by distinguishing five different grades of extramissive involvement, some, if not all, are at the core of Augustine's thinking. Second, in light of the distinguishable grades of extramissive involvement, we shall briefly review the strength of the evidence for attributing an extramission theory to Augustine on the basis of his other works. We shall see that, at best, it is neither required by scripture nor reason, but represents authoritative opinion, such as Plato's, Ptolemy's, or Galen's, and so is, by Augustine's lights, a defeasible commitment, albeit a commitment he explicitly rejected in DQA. More importantly, of the five grades of extramissive involvement, only the first three are central to Augustine's thinking about perception. But only the fourth grade involves a genuine extramissive element, and a full commitment to a pure form of the extramission theory only comes with the fifth. 


\section{The Textual Evidence}

The textual evidence for attributing to Augustine an extramission theory occurs in chapter 23 of DQA. The primary evidence consists in two passages from DQA 23.43, but there is also a back reference to the second passage at the beginning of DQA 23.44. In this section, I shall argue that the textual evidence is less conclusive than is commonly supposed. But that the extramissionist reading could not be right is only really established in section 5 where we discuss Augustine's reply to Evodius' puzzle.

The first passage is as follows:

Sight extends itself outward and through the eyes dart forth in every possible direction to light up what we see. (DQA 23.43, Colleran 1949, 66)

As Colleran's translation indicates, the Latin pronoun is takes as its antecedent visus from the previous line. Visus can be translated as vision or sight, but sight is the appropriate translation as the present passage seems to be describing its actualization. On the extramissionist reading, this passage is describing the emission of the visual ray.

The second passage involves the stick analogy that Alexander of Aphrodisias attributes to the Stoics in De anima 130.14:

I say that be means of sight, reaching out to that place where you are, I see you where you are. But that I am not there, I admit. Still let us suppose that I were to touch you with a stick: I certainly would be the one doing the touching and I would sense it; yet I would not be there where I touched you. (DQA 23.43, Colleran 1949, 66)

On the extramissionist reading, seeing by means of the visual ray is likened to touching something with a stick. The visual ray, like the stick, is a rectilinear, continuous unity.

Let us begin with the first passage. It can seem, and has seemed to some, that it is an unambiguous expression of the extramission theory. How else is one to understand visus from the eyes? (Here, I am deliberately echoing Turnbull 1978, 13-14.) That sight extends itself outwards through the eyes seems like a reasonable description of looking and seeing, at least as a Platonist conceives of it. But the outward activity of looking and seeing is not the exclusive provenance of the extramission theory. The Platonic element of Augustine's description consists in two things, the first more explicit than the next. First, sight is a power of the soul that is exercised through the use of the eyes. It is an instrument of the soul (DQA 33.41, De Gen. ad lit.12.24.51). That the body is an instrument of the soul is a distinctively Platonic thought (compare Plato, First Alcibiades $129 d$, Plotinus, Ennead 4.7.8). Second, Augustine is here emphasizing how seeing is an activity of sight, a power of the soul. The superiority of the incorporeal soul is manifest in its ability to act upon the sensible and corporeal without the sensible and the corporeal being able, in turn, to act upon the soul (De musica 6.5.8-10; see Silva 2014 for discussion). So, it is the soul that acts in seeing and so places itself in the distal body seen (Colleran 1949, 205, n.55). The emphasis here is on the activity of the soul as opposed to its being substantially located where the perceived object is.

The outward activity of looking and seeing is not the exclusive provenance of the extramission theory. One might object that this ignores the illuminationist imagery at the end of the passage-sight darts forth from the eyes and illuminates what it sees. While it is true that the visual ray of the extramission theory is often likened to light (Empedocles, DK 31b84, Plato, Timaeus $45 \mathrm{~b}-\mathrm{c}$ ), the illuminationist imagery, considered by itself, is insufficient grounds for the attribution of the extramission theory to Augustine. Other thinkers, who have explicitly rejected the extramission theory, have coherently embraced this imagery. The illuminationist imagery is undoubtedly of Neoplatonic origin, but neither Plotinus nor Porphyry are extramission theorists. Neither are lamblichus, Proclus, Priscian, nor Pseudo-Simplicius. In addition, later scholastic thinkers influenced by Augustine employ the Neoplatonic illuminationist imagery while disavowing the extramission theory. Thus, Peter John Olivi compares a perceiver's gaze to light illuminating 
its object (Quest. in sec. lib. Sent. q. 72 35-36) even as he denies that seeing involves any real emission (Quest. in sec. lib. Sent. q. 58 ad 14.8). Merleau-Ponty $(1967,185)$ will echo both aspects of Olivi's position. For Merleau-Ponty, the illuminationist imagery captures the active outward phenomenology of looking and seeing even if the extramission theory provides a false causal model of perception.

How might the illuminationist imagery be understood if it is not, indeed, committed to the extramission theory (for discussion see Kalderon 2018, chapter 5)? The awareness afforded by visual experience is like a beam of light that manifests the latent presence of its object. Vision, like illumination, has direction. Light is emitted outward from its source upon the scene that it illuminates. Vision too is outer-directed. In seeing, the perceiver looks out upon the scene before them. Not only do vision and light have direction but they are both rectilinear as well. Thus, we speak of lines of sight and do so innocent of any commitment to extramission. Moreover, just as illumination manifests the latent visibility of an object, seeing an illuminated object manifests its latent presence to the perceiver revealing it to be where it is. The explicit awareness of the natural environment afforded by visual experience is akin to light not only in its rectilinear directionality and its power to manifest latent presence, but in the manner in which it discloses distal aspects of that environment. Just as the illumination alights upon the object it illuminates at a distance from its source, the perceiver's gaze alights upon the object of perception at a distance from their eyes. The imagery here not only emphasizes that vision is a kind of perception at a distance but invokes an active outward extension. The acceptance of the analogy, so explicated, is consistent with no part of the perceiver being substantially located where the perceived object is and so bears no commitment to the active outward extension being specifically spatial.

In addition to the phenomenological aptness of the illuminationist imagery, Augustine may have had another motive in deploying it, one that is consistent with the rejection of the extramission theory. Corporeal light may be the means by which we see, but spiritual light is the means by which we understand. The doctrine of illumination was first stated in De magistro written during the same period as the present dialogue (on the doctrine of illumination see Allers 1952 and Matthews 2014). Augustine understands corporeal light as the image, in the Platonic sense, of the true spiritual light. Insofar as perception, like the understanding, involves a mode of awareness, the illuminationist imagery may be the joint result of Augustine's doctrine of illumination - that spiritual light is that by which we understand-and the claim that perceptual activity is an image of intellectual activity.

Finally, a defender of the extramissionist reading might object that we are overlooking the final line of the quoted passage where it is maintained that vision occurs where the object is seen and not at the place where sight goes out from. It is true that if vision occurs through the emission of a visual ray, then this is well explained. However, while the extramission theory may explain this claim, that explanation is not indispensable. Augustine, here, is echoing a Neoplatonic doctrine, that perception places the perceiver in the object perceived, shared by Plotinus and Porphyry, neither of whom were extramissionists. Augustine seems to have in mind, here, not the extramission theory, but the phenomenology of attentive awareness. Perception places us in the perceived body. That is where the perceiver's attentive awareness is. In selectively attending to an object of your experience, where is your attention? On the object selectively attended to, of course. The query, "Where's your head at?", gives expression to this. Your "head" is where the object of your attention is. In general, an act or episode of attention is where its object is. Attention is not the kind of thing that has location in itself. Attention is conceived by Augustine to be an incorporeal power of the soul to direct the mind to various objects. Insofar as attention can be said to have location, it must inherit this location from the location of its object. This, then, is the claim about the phenomenology of attentive awareness, that attention is located where its object is. One need not be an extramission theorist to endorse it (for further discussion of this point see Kalderon 2018, chapter 6.5).

The first passage, while not, by itself, sufficient grounds for attributing to Augustine an extramission theory, may gain new force and significance, however, when considered in context with the second passage. Recall, there, Evodius likens looking and seeing a distal object to touching it with a stick. On the extramissionist reading, this is a description of visual rays 
extending from the perceiver to the distal object. Like the stick, the visual ray is a continuous unity that spatially extends from the perceiver to the object perceived. Should we accept the extramissionist reading? A number of observations are relevant here.

First, Evodius is adapting the Stoic stick analogy (Alexander of Aphrodisias, De anima 130 14) (for recent discussion of the influence of Stoicism on Augustine see Brittain 2002, Byers 2013, and Sellars 2013). The Stoic analogy is criticized by Galen in De Plac. Hipp. et Plat. 7.7, and Tideus in De Speculis, and subsequently echoed by Descartes (1637) in La Dioptrique, though for his own, distinctively modern, purposes. That analogy is plausibly rooted in, and an interpretation of, Plato's Timaeus 45b-c discussion of perception (see Lindberg 1977, chapter one). A primeval fire within the eye, that gives light but does not burn, extends out through the pupil. There it encounters what is like it, external light. And together they constitute a continuous unity, a compound of emitted light and external light, extending from the perceiver to the distant object of perception in a rectilinear path. The stick analogy captures the formal features of the Timaeus account, namely, that the compound of emitted light and external light constitutes a continuous, rectilinear unity-just like a straight stick. However, these formal features are preserved in accounts given by thinkers that explicitly reject the extramission theory. And if that is right, then the stick analogy is not sufficient for the attribution of an extramission theory.

Consider, then, one prominent account. Aristotle rejects the extramission theory as providing a false causal model of perception (De sensu $2438^{\mathrm{a}} 26-438^{\mathrm{b}} 2$ ), and yet his alternative causal model preserves these formal features. The illuminated media intervening between the perceiver and the distant object of perception already, according to Aristotle, constitutes a continuous unity (De anima $2.7419^{\mathrm{a}} 12-22$ ). But the resulting account is broadly intromissionist in that it emphasizes the perceived object acting upon the perceiver, albeit mediately. Specifically, the perceived object immediately acts upon the medium, a continuous unity, which in turn immediately acts upon the perceiver. In this way, the perceived object mediately acts upon the perceiver.

Acceptance of the Stoic stick analogy is not sufficient for commitment to the extramission theory. Indeed, Descartes, in La Dioptrique, accepts the Stoic analogy even though his mechanical explanation of vision is in no way extramissive. Nor, indeed, is it necessary. Galen, in De Plac. Hipp. et Plat. 7, rejects the Stoic analogy even as he embraces the extramission theory.

Another worry concerns the specific use to which Evodius is putting the Stoic stick analogy. It is commonly accepted that the extramission theory is one way of modeling vision on the basis of touch. Touch may be a contact sense, but distal senses, such as vision, may be modeled on touch if the emitted visual ray extends to the distant object of perception and is in contact with it. A specific form of touch is here accepted as paradigmatic, namely, sensation by contact. But sensation by contact is not the only form of touch. Thus, Broad (1952) distinguishes a dynamical form of touch-haptic touch in modern psychological parlance-from sensation by contact. But the conception of touch involved in Evodius' adaption of the Stoic stick analogy is not sensation by contact. Rather, it is a specific and atypical form of haptic touch. It is a form of haptic touch since touching something with a stick - "poking" - is an activity and so displays the dynamical character of haptic touch. What is distinctive about this form of haptic touch is that involves a form of distal touch, where the felt object is not in direct contact with the perceiver's body. This form of haptic touch is atypical in that most forms of haptic touch involve contact and not all involve an instrument or intervening medium. So, consider feeling the wooden frame through the padding of a Victorian hobby horse. The perceiver feels the wooden frame even though they are not in direct contact with it. Instruments, such as a stick, can be exploited in distal touch. Thus, by means of a stick one may feel the texture of a distant surface, or its hardness and rigidity. One feels the tactile qualities of the distant surface through the stick, despite not being in direct contact with it.

The advertised worry turns on two observations. First, Evodius' appeal to distal touch is in tension, if not inconsistent, with the extramission theory. The extramission theory is motivated by the idea that the perceived object must be in contact with the sense. But, again, the paradigmatic conception of touch is sensation by contact and not distal touch. In a way, Augustine, at this point of the dialogue, has elicited a dialectical concession from Evodius (albeit one whose full significance Evodius will only realize in chapter 30 ). The extended discussion of perception is 
inaugurated by a puzzle Evodius raises about the incorporeal nature of the soul. If the soul is not extended throughout the body, then how can it feel wherever the body is touched? Evodius' implicit thought, here-that the perceived object must be in contact with the sense, understood not merely as a sense organ, but that organ as animated by the sensitive soul, the principle of sensation-is now abandoned. One can feel what one is not in direct contact with. It is because Evodius is walking back from a previous commitment, shared with the extramission theory, that this is properly regarded as a dialectical concession.

Second, there is an oddity in Evodiues' description of distal touch. Using an instrument, such as a stick, to feel a distant textured surface, it seems, from within, that we experience that texture at the end of the stick. "As if your nervous system had a sensor out at the tip of the wand", as Dennett $(1993,47)$ observes. That is, in cases of distal touch, you feel tactile qualities where they are. But Evodius seems to disavow that: "I certainly would be the one doing the touching and I would sense it; yet I would not be there where I touched you" (DQA 23.43, Colleran 1949, 66). But such a disavowal seems to be in tension with, not only the phenomenology of distal touch, but also with the extramission theory as usually understood. If the eye emits a visual ray that extends to the distant object of perception so that it is in contact with it, then at least a part of the perceiver is substantially located where the perceived object is, or is, at the very least, contiguous with it. And it is there, at the point of contact, that the object is sensed. Compare the view that Nemesius attributes to Hipparchus, "Hipparchus says that rays extend from the eyes and with their extremities lay hold on external bodies like the touch of hands" (De natura hominis 7; Sharples and van der Eijk 2008, 104), not to mention Euclid's third definition in his Optics, "Those things are seen upon which the visual rays fall; the things upon which the visual rays do not fall are not seen" (Burton 1943, 357)

As we shall see in the next section, the dialectical situation is this: Augustine has just put forward in chapter 23 what is to be the main conclusion of the subsequent sequence of chapters culminating in chapter 30 , that in seeing the perceiver is affected where they are not. Evodius in chapter 23 tries to resist this conclusion by means of the stick analogy. In chapter 30 , after the many important clarifications of the intervening chapters, Evodius comes to accept that conclusion on the basis of Augustine's argument, first bruited in chapter 23. So Evodius' response, his use of the stick analogy in chapter 23, could not be Augustine's considered view, and, hence, could not be a basis for attributing the extramission theory to Augustine or, indeed, anything else. What is more, if at least Dennett is to be believed, it is phenomenologically inept, and, more importantly, inconsistent with the principle driving the extramission theory, and so constitutes a dialectical concession, though one that Evodius himself will not recognize until chapter 30.

\section{Dialectical Context}

The force of the textual evidence for attributing an extramission theory to Augustine, in DQA, crucially depends upon the dialectical context. Allow me to briefly review the place of Augustine's account of perception in that dialogue.

DQA is mainly charged with the task of arguing for the incorporeal nature of the living soul. In the dialogue, Evodius, like Augustine's former self (Confessiones 7.1ff), has a hard time conceiving of something that is both real and incorporeal (compare the position of the Giants in Plato's Sophistes 246a). Throughout DQA, Augustine will give accounts of the soul's powers and activities that are meant to persuade us that these are not powers and activities of the body. The question of the soul's incorporeal nature is linked with the question of its magnitude. Bodies are extended in three dimensions. If souls are inextended, if they lack extensive magnitude, then they are incorporeal. But, importantly, being incorporeal is consistent with the soul's possession of superior virtual magnitude. That is to say that psychic powers, the powers and virtues of the soul, are superior to any corporeal power.

Augustine thus distinguishes two senses of magnitude (DQA 3.4):

1. Extensive magnitudes: magnitudes of extension, "How tall is Hercules?" 
Evodius seeks an answer to the question in both senses. In the sense of extensive magnitude, Augustine denies that the soul has quantity at all. The soul is inextended, and, hence, incorporeal since corporeal bodies are necessarily extended in three dimensions. Augustine's denial concerns continuous quantities like magnitude and not discrete quantities like number. In denying that the soul has quantity, Augustine is not denying that there are numerically distinct souls. Augustine will maintain that the soul, while lacking extensive magnitude, nevertheless possesses virtual magnitude. Whereas the question how great is the soul in the sense of extensive magnitudes is answered in the negative in DQA 3.4, a full answer to the question how great is the soul in the sense of virtual magnitude, in its powers and virtues, only emerges in the hierarchically organized enumeration of the soul's powers that ends the dialogue (DQA 33-36; see Brittain 2003 for discussion). This hierarchically organized enumeration of the soul's powers is also, at the same time, a soteriology, at least in part, in that it describes the soul's ascent to God (and it is in this sense that it is a theoretical articulation of the vision in Ostia that Augustine shared with Monica as reported in the Confessiones $9.10 .24-5)$.

Evodius will resist Augustine's denial that the soul possesses extensive magnitude. Extensive magnitudes cited by Augustine are length, width, and strength. A third spatial dimension, height, is latter added, DQA 6. Strength here translates robustam which means the resistance offered by solid objects that occupy space. Specifically, then, Evodius doubts whether something without length, width, height, and strength so much as could exist. Here, Evodius is echoing the position of the Giants in the Sophistes. In response, Augustine will offer a negative argument and a positive argument. According the negative argument, just because the soul lacks extension does not mean that it is not real (DQA 3.4- 4.5). And according to the positive argument, the soul must be incorporeal since it possesses powers that bodies lack (DQA 4.615.25).

In the Sophistes, the Eleatic Visitor convinces the Giants to modify their corporealism in order to allow for justice, since denying the existence of this virtue would be impious. Justice lacks length, width, and height. It cannot be grasped and offers no resistance to touch and hence lacks strength, robustam. And it is by means of the Eleatic Visitor's argument that Augustine convinces Evodius that lacking extensive magnitude does not entail nonexistence. (It is unclear whether the Platonic influence is direct, but as Augustine had read the books of certain Platonists, Confessiones 7.9.13, possibly the Latin translations of Plotinus and Porphyry by Marius Victorinus, the Platonic influence may well be indirect.) Specifically, a tree, a sensible and corporeal object with extensive magnitude, exists. But so too does justice despite lacking extensive magnitude. Moreover, and importantly, justice is greater in value than the tree. The adaption of the Eleatic Visitor's argument is meant to establish not only that virtues like justice may exist despite being inextended but that they may also be more excellent than any extended thing. Justice may lack extensive magnitude and yet possess greater virtual magnitude than any sensible body.

Augustine may have established that the soul's nonexistence does not follow from its lack of extension, but he has yet to establish what the soul positively is. Moreover, just because justice is real despite being inextended, it does not follow that the soul itself is inextended. Evodius is persistently attracted to the idea that the soul extends throughout the body that it animates and hence must itself be extended. Augustine will argue, in contrast, that the soul is inextended because it possesses powers that corporeal extended things lack. In effect, Augustine is arguing that the soul possesses greater virtual magnitude than any extended corporeal thing. It is the greatness of the soul that establishes its inextended, and hence, incorporeal nature.

Augustine's argumentative strategy is to emphasize how an account of the powers and activities of the soul establish that they are not powers and activities of a body. Indeed, so construed, Augustine offers not one positive argument but two: 
1. In visually imagining a remembered body, my mental image is not constrained in the way that corporeal images are. Corporeal likenesses are only as large as the body in which the image occurs, incorporeal likenesses are not so constrained (DQA 5.7-9)

2. In conceiving of geometrical figures abstracted from three-dimensional bodies - such as planes, lines, and points that figure as parts of those bodies - the soul must be incorporeal since only like can conceive of like (DQA 6.10-15.26)

At this point the central case of the dialogue has been made. That is to say, Augustine has argued that just because something is incorporeal does not mean that it is less real or less valuable than something corporeal. Moreover, Augustine has argued that the soul must be incorporeal because it possesses powers that corporeal extended things lack. And that the incorporeal powers of the soul are either more valuable than their corporeal counterparts or at least more valuable than the corporeal objects of their activity.

Evodius accepts that Augustine has established this. What are raised, at this point, are less objections per se to Augustine's conclusions than certain residual puzzles or aporiai. There are two:

1. If the soul is inextended, how is it that the soul grows over time as the body grows? (DQA 15.26-22)

2. If the soul is inextended, then it is not extended throughout the body. But if the soul is not extended throughout the body, then how can it feel wherever the body is touched? (DQA 23-30)

It is the second residual puzzle that prompts the extended discussion of perception.

A tacit assumption is at work in Evodius' second puzzle. Attending only to sensation by contact, and perhaps by regarding it as an exemplary form of perception, can suggest that the principle governing sensation takes a certain a form. Its slogan might be: to be perceptible is to be palpable (see Kalderon 2015 for discussion). The idea is that the perceived object must be in contact with the principle governing sensation. The sensitive soul is the principle governing sensation. Wherever Evodius is touched upon his body he feels it. That means that the principle of his sensation, Evodius' sensitive soul, must be in contact with what touches his body, if it is to be perceptible. But it is perceptible. And so the sensitive soul, at least, must be extended throughout the body.

Augustine is sensitive to this tacit assumption even though he does not make it explicit. This sensitivity is manifest in a curious shift in example. Whereas Evodius' objection turns on an observation about touch, understood as sensation by contact, Augustine develops his definition of perception with reference to vision, a form of distal perception. The objects of vision must be at a distance from the perceiver's eyes. Augustine's intent is to undermine the tacit assumption driving Evodius to think that the soul must be extended throughout the body if sensation by contact is to be so much as possible. Augustine's intent is to undermine the assumption that to be perceptible is to be palpable, that the perceived object must be in contact with the principle governing sensation. This assumption not only drives Evodius' puzzle, but the extramission theory as well.

\section{The Definition}

When asked by Augustine what sense perception is, Evodius, good Socratic stooge that he is, merely responds with a list, the Peripatetic five senses-vision, audition, olfaction, taste, and touch. Augustine explains that they are presently seeking a single definition that would encompass all five senses (compare, for example, Plato, Theaetetus 145e-147c) and proposes a candidate definition for Evodius to defend or reject. This definition will subsequently be refined, though it will retain its basic form. It is worth, however, discussing the initial formulation of the definition:

Perception, I think, is what affects the body not being hidden from the soul 
Augustine's provisional definition comes in two parts: quod patitur corpus describes the object of perception whereas non latere animam describes the soul's relation to that object.

Consider the soul's relation to the object of perception first. And bracket, for the moment, the significance of Augustine's indirect description of that relation. In describing the object of perception as being not hidden from the soul, Augustine is defining perception, in the first instance, as a mode of awareness (Brittain, 2002, 275).

What is the significance of Augustine's indirect description of the soul's relation to the object of perception? Why describe the object of sensory awareness as something that is not hidden from the soul? Some have found this worrying. Bourke $(1947,112)$ flatly pronounces Augustine's definition "unsatisfactory" on just this basis: "The persistent use of the negative formula (non latere) indicates Augustine's inability to say positively just what sensation is." And Bourke's judgment is reaffirmed by McMahon (1947, 104, n.1 and Gannon 1956, 167-8, raises a similar worry). However, I wonder to what extent Bourke's judgment is fair. If we accept, as seems evident, that Augustine had in mind a mode of awareness, then perhaps to describe the object of perception as not hidden from the soul is, after all, to provide a positive characterization of the sensory awareness afforded by perceptual experience.

Etienne Gilson thought so:

His purpose is to make sensation an activity of the soul within the soul itself. This is really the reason why he defines it in such a roundabout way. The phrase "non latet" indicates precisely that the soul is a spiritual force, ever watchful and attentive. In order to sense, it does not have to receive anything from the organ that it vivifies; it is enough if the changes undergone by the organs do not escape its notice, and come within the range of its attention. (Gilson, 1961, 63)

Notice how Gilson understands something not being hidden from the soul as the effect of the soul's attentive vigilance. The positive characterization that Gilson sees in Augustine's roundabout expression is metaphysically significant. That something is not hidden from the range of the soul's attention is due to the activity of the soul within the soul itself. I believe that Gilson was right to see in Augustine's roundabout expression a positive characterization of sensory awareness. Consistent with Gilson's suggestion, one might also understand Augustine as claiming that sensory awareness is a mode of disclosure. To describe the object of perception as not hidden from the soul is to understand sensory awareness not only as the soul's attentive vigilance but also as a mode of disclosure-an activity whereby what was previously hidden from the range of its attention is now revealed to the soul.

Moreover, this indirect description of the awareness involved in perception, non latere, has Platonic roots, $\mu \eta^{\prime} \lambda \alpha \nu \theta \nu \varepsilon i \nu$, and Augustine may have picked it up from his encounter with the books of the Platonists (Confessiones 7.9.13). It can be found in Philebus 33d and 43cand in Timaeus $64 \mathrm{a}-\mathrm{c}$. This usage is picked up by later Platonists. It can be found, for example, in Plotinus' Enneads 4.4.18-19. So, the negative formulation is not due to Augustine's inability to say positively what sensation is, as Bourke contends, rather he is picking up on a Platonic gloss on awareness (see O'Daly 1987, 86 n15 and Brittain 2002, 275 n61 for further discussion).

Consider now Augustine's description of what is not hidden from the soul, the object of sensory awareness. Brittain $(2002,274-278)$ claims that there is a crucial ambiguity in quod patitur corpus. The verb patior means to suffer or undergo, to be affected. So, a natural understanding of this phrase might be what the body undergoes. Here corpus is understood as the subject of the verb patior. What the body undergoes is a bodily affection, the way in which the body is affected. However, quod patitur might also be read as Latin rendering of the Greek o $\tau$ เ $\pi \dot{\sigma} \sigma \chi \varepsilon l$. So understood, quod is nominative, not accusative, and is the subject of the verb patior. On this reading, the object of sensory awareness is less a bodily affection than what affects the body. What affects the body is the causal agent of the bodily affection, whereas what the body 
undergoes is the bodily affection elicited by that cause. On the former understanding, the object of sensory awareness is internal-it is the perceiver's body being affected in a certain way. On the latter understanding, the object of sensory awareness is external, at least if we rule out cases of auto-affection - it is what affects the body from without.

Whether or not quod patitur corpus is ambiguous in the way that Brittain claims it to be, understanding that phrase as what affects the body better coheres with Augustine's own examples of the objects of perception in DQA. The objects of vision, for example, are external bodies located at a distance from the perceiver. Thus, Augustine sees Evodius, and Evodius sees Augustine, and neither is at the place where the other is. The objects of perception are external to the perceiver's body. In modern psychological parlance, perception is exteroceptive. And this would remain true even if the sensory disclosure of external bodies involves the perceiver's sensory organs being affected, or even the formation of incorporeal images in the soul occasioned by such affections. Understanding quod patitur corpus as bodily affection yields a definition of what is, at best, bodily sensation. It at best characterizes a form of interoceptive awareness. Interoceptive awareness contrasts with exteroceptive awareness in that it is an awareness, not of what is external to the body, but of the body itself. It is only on the understanding of quod patitur corpus as what affects the body-understood as the external causal agent of the bodily affection -that it plausibly yields a definition of perception. Only so understood does the definition characterize a form of exteroceptive awareness. After all, what affects the body, the objects of perception, are external that body, and the objects of visual perception are located at a distance from the perceiver's body. Moreover, as we have emphasized (section 3), it is dialectically important that Augustine is discussing vision, a distal sense.

If perception fundamentally involves the soul's sensory awareness understood as a mode of disclosure, and if the objects not hidden from the soul are external bodies, then the emphasis of the expression quod patitur corpus is on the fact that the soul's sensory awareness of external bodies is mediated by the body's affection. In this way perception contrasts with understanding. The soul's awareness of the intelligible is not mediated by the body's affection the way that the soul's sensory awareness is. Augustine explicitly distinguishes perception (sensus) and the awareness that it involves from knowledge (scientia) and the awareness that it involves (DQA 29). Summarizing that discussion Augustine opens DQA 30 with the claim that perception is one thing, knowledge is another (aliud sensus, aliud scientia), even though not being hidden from the soul is a common element of both. However, what is not hidden from the soul differs in these cases in whether what is disclosed is made apparent through the frame of the body or through pure intelligence (sive per temperationem corporis, sive per intelligentiae puritatem). This clearly shows that quod patitur corpus or passio corporis are used to specify the relevant kind of awareness involved in perception, a kind of awareness disclosed through the body's affection, a kind of awareness that Augustine explicitly contrasts with the awareness involved in knowledge.

More refined versions of the preliminary definition will be given in DQA 25.48, 26.49, and 30.59. There are two salient differences between the preliminary definition and the refined versions.

First, quod patitur corpus has been replaced by passio corporis (or, equivalently, corporis passio - the variation in word order makes no difference to the Latin grammar). Passio corporis is most naturally read, not as what affects the body, but the body's affection, what the body undergoes when being affected from without. However, as we observed before, so understood, the definition does not define perception but bodily sensation. But it is clear and important that Augustine is not only discussing perception but a form of distal perception, vision. So passio corporis is a kind of Augustinian shorthand for quod patitur corpus that is meant to inherit its sense. So, this first difference is superficial and does not represent a genuine refinement of the definition.

Second, each of the refined versions include a new phrase, per seipsam, which can be translated as by itself or directly. Unlike the substitution of passio corporis for quod patitur corpus, 
this is not a superficial difference but does represent a genuine refinement of the definition. How are we to understand this refinement and what is the nature of its grounds?

The refinement of the preliminary definition was prompted by a counterexample to its sufficiency. Growth is an affection of the body not hidden from the soul and yet it is insensible. According to Augustine, such failures, where the definition encompasses more than it undertook to explain, can sometimes be fixed with an emendation (DQA 25.47). Thus, Augustine's challenge to Evodius (DQA 25.48): What qualification can be added to the definition to render it valid? Evodius' answer (picking up on an earlier claim of Augustine's, DQA 24.46, whose significance he did not, at that time, understand) is per seipsam. What is the force of the qualification? Growth is an affection of the body not hidden from the soul and yet growth is insensible. That is why it represented a failure of sufficiency of the initial formulation of the definition. However, it is not true that growth by itself is not hidden from the soul. Growth only falls within the range of the soul's attention by the operation of reason and intellect. In contrast, the perceived object affecting the eyes is by itself not hidden from the soul.

The structure of Augustine's definition is metaphysically telling. The distal object acts upon the animated sense organ occasioning the sensitive soul to direct its attentive awareness to what affects that organ. First, notice that it is only the sense organ, and not the sensitive soul itself, that is affected by the object of perception. Plausibly, this is an instance of the prohibition on ontological inferiors acting upon ontological superiors. The sensible and the corporeal may act upon the sense organ, but not the sensitive soul that animates it (De musica 6.5.8-10; see Silva 2014 for discussion). Moreover, as we shall see in the next section, the sense organ is only affected in the way that it is because it is animated by the sensitive soul (compare Priscian, Metaphrasis 2.1-2). Though the object of perception does not act upon the sensitive soul, it is not hidden from the range of the soul's attention. That something is not hidden from the range of the soul's attention is due to the activity of the soul within the soul itself.

Not only will Augustine criticize the preliminary definition to motivate its refinement, but he will also clarify a number of issues that might stand in the way of accepting the definition. These tasks will be pursued in chapters 24 to 29 . It is only when we have the refined definition, and the obstacles to accepting it have been eliminated, does Augustine apply that definition, in chapter 30 , to answer Evodius' challenge to the incorporeality of the soul-to explain how it is that the soul feels wherever the body is touched if it is not extended throughout the body.

\section{Augustine's Counterargument}

Augustine counterargument begins with a restatement of the refined definition whose validity has been accepted by Evodius and Augustine (DQA 25.48, 26.49, and 30.59):

1. Perception is what affects the body by itself not being hidden from the soul.

From the accepted definition it immediately follows that:

2. If one perceives, one's body is acted upon.

Moreover, it was earlier (DQA 23.42) agreed that:

3. Seeing is a form of perception.

But seeing is in some ways a distinctive form of perception. It is a mode of distal perception. Importantly, it was also agreed that:

4. A perceiver sees an object where the perceiver is not. 
If sight were confined to where the perceiver is at, at best the eye alone could be seen. But the objects of sight are located at a distance from the perceiver. So, the perceiver sees an object where they are not.

From these premises a startling conclusion follows. Seeing is a form of perception. If one perceives, one is acted upon. So, in seeing one is acted upon. And since what acts upon one when one sees is located where one is not, in seeing one is acted upon where one is not. The conclusion involves attributing to the animate eye a passive power to be affected where it is not. In Dutton's (2020) apt phrase, the eye is subject to passion-at-a-distance (Dutton's essay is an excellent discussion of the present argument). This is a passive power not shared with soulless natural bodies. Inanimate natural bodies can only be acted upon by what is in contact with them. The living eye, part of a whole and healthy animal, is animated by the sensitive soul, and it is a manifestation of the superiority of the soul that it endows the eye that it animates with the passive power to be affected where it is not. The sensitive soul may lack extensive magnitude, but it has, in this way, great virtual magnitude. This nicely fits the pattern we observed in Augustine's positive argument for the inextended nature of the soul. This involved attributing superior powers to the soul not possessed by extended corporeal things. Thus, while corporeal images are limited by the size of the body upon which they are inscribed, the soul's power to recall an image of an object previously seen is not subject to this limitation. Similarly, the soul possesses the power to conceive of incorporeal geometrical abstractions, and since only like may conceive of like, the soul itself must itself be incorporeal. It thus possesses a power that no corporeal thing may have. The passive power to be affected where one is not conferred by the sensitive soul is similarly a power that no soulless body may possess. Further testimony to the greatness of soul, conceived, not as greatness of extent but greatness of power or virtue.

A commitment to the animate eye possessing the passive power to be affected where it is not is one that Augustine shares with thinkers who explain the eye's affection in terms of sympathy (Cleomedes Meteōra, Plotinus Ennead 4.4- 6, Porphyry Ad Gaurum; Epicurus, Letter to Herodotus also invokes sympathy in his account of perception, but not to explain action at a distance, but rather to explain the unity of the streams of eidola, see Lee 1978). The sympathetic affection of the animate eye is the result of action at a distance, and so the animate eye possesses a passive power to be affected where it is not. In contrast with the Stoics, Epicureans, and Neoplatonists, Augustine does not appeal to sympathy as an explanatory principle, nor indeed does he explain the passive power in terms of any other principle (for discussion see Gannon 1956, 168 n53). We are merely meant to marvel at this power that the sensitive soul endows the eye with, a power superior to any passive power of a soulless natural body.

How does this attribution of a passive power possessed by no purely corporeal thing bear on Evodius' puzzle? Recall the tacit assumption behind Evodius' use of sensation by contactthat the object of sensation must be in contact with its principle, that by which one senses. It is just this assumption that drives Evodius conviction that the soul must be extended throughout the body. For only if it were could it be in contact with what touches the body. But if the sensitive soul confers the passive power to be affected where one is not, then there is no need for the sensitive soul to extend throughout the body. The soul need not be where the body is affected, at least substantially, for this affection to be not hidden from the range of its attention (DQA 30.59). Though the writing has been on the wall since chapter 23, Evodius is stunned:

That conclusion upsets me very much, so much, in fact, that I am completely stunned. I do not know what to answer and I do not know where I am. What shall I say? Shall I say that a bodily [affection] of which the soul is aware directly is not sensation? What is it, then, if it is not that? Shall I say that the eyes [are affected by] nothing when we see? That is most absurd. Shall I say that the eyes [are affected] where they are? But they do not see themselves and nothing is where they are, except themselves. Shall I say that the soul is not more powerful than the eyes, when the soul is the very power of the eyes? Nothing is more unreasonable. Or must this be said, that it is a sign of greater power to [be affected] there where something is than to [be affected by] it where it is not? But, if that were true, sight would not be rated higher than the other senses. (DQA 30.60; Colleran 1949, 87, with modifications) 
The reason that corporeal things lack the passive power to be affected where they are not is because, being corporeal and extended, they are confined to the place where they are. The soul, being inextended and not so confined, may confer this passive power on a body that it animates. Augustine thus explicitly rejects the principle that drove Evodius' aporia - to be perceptible is to be palpable to sense, that the perceived object must be in contact with the principle governing sensation. But this is the principle that drives extramission theories as well. Thus, Augustine's counterargument is an anti-extramission argument. A failure to recognize this, and so misattribute to Augustine a commitment to extramission in DQA, is due, at least in part, to unclarity about the commitments of the extramission theory.

\section{The Grades of Extramissive Involvement}

It is worth getting clear about what, exactly, it means to describe perception as extramissive. In doing so, however, we should bear in mind that the distinction between extramission and intromission theory arises in the historiography of perception, and that theories classified by historians as extramissive may have competing theoretical goals. Thus Lindberg (1978) distinguishes two forms of extramission theories (conspicuously leaving open that there are others.) The goal of the first form of extramission theory was to provide a mathematically coherent account of perspective, refraction, reflection, and so on. This is most clearly exhibited in the tradition of geometrical optics which included Euclid, Hero, Ptolemy, and Al-Kindi. The goal of the second form of extramission theory was not to provide a mathematically coherent account of these matters, so much as to provide a physiological and psychological explanation of vision. Galen's account of vision in De Plac. Hipp. et Plat. is a good example of this second form of extramission theory. Augustine's ambitions in writing about perception are more in line with Galen's than Euclid's and so we will focus on the second form of extramission theory. (On the influence of Galen's physiology on Augustine's account of perception see O'Daly 1987, chapter 3.1.)

On the basis of our discussion so far, we are in a position to usefully distinguish different grades of extramissive involvement (the allusion to Quine 1953 is deliberate; for a similar approach to the commitments of the extramission theory see Licka 2020). The grades are meant to be applied successively, so, for example, a commitment to the fifth and highest grade involves a commitment to the previous four grades. It is only the fourth grade that introduces a genuine extramissive element, but it is only the fifth and highest grade that incurs a full commitment to a pure form of extramission:

1. Perception must at least centrally involve the activity of the perceiver;

2. This activity is outer directed-in the case of vision, this outer-directed activity is rectilinear;

3. This outer-directed activity of the perceiver constitutes, at least in part, their perception;

4. This outer-directed activity that constitutes, at least in part, the perception of an object involves something spatially extending to the distal object of perception -in the case of vision, along a rectilinear path - so that at least part of the perceiver is substantially located where the perceived object is or is, at the very least, contiguous with it; 5. To be perceptible is to be palpable, the perceived object must be in contact with the principle governing sensation, a principle spatially extended from the perceiver to the perceived object.

As we shall see, only the first three grades are central to Augustine's thinking about the nature of perception.

The first grade is far too weak to incur genuine commitment to extramission. Perception is not even identified with activity, let alone extramissive activity, but is only claimed to centrally involve activity. Many thinkers accept that perception at least centrally involves activity without accepting, as well, the extramission theory. 
The first two grades, considered jointly, are insufficient for extramission. Taken together they are equivalent to the claim that vision centrally involves rectilinear, outer-directed activity. So understood, they might reasonably be taken to jointly describe looking and seeing. It is not implausible to think that in order to visually perceive an external scene, the perceiver must look at that scene, where looking involves directing one's visual awareness to that scene. Looking, so conceived, is an outer-directed activity of the perceiver that is rectilinear. It determines a line of sight. Plausibly though it may be, the principle - to see, one must look - is a substantive claim that not all may endorse. And yet it falls short of the extramission theory. Notice that the first two grades jointly capture Augustine's claim when he writes "Sight extends itself outward and through the eyes darts forth far in every possible direction to light up what we see" (DQA, 23 43; Colleran $1949,66)$. But as these fall short of the extramission theory, this passage is insufficient grounds to attribute an extramission theory to Augustine as I have argued in section 2. Notice, as well, that in determining lines of sight, the first two grades form a sufficient basis for geometrical optics of the kind developed by Euclid, Hero, Ptolemy, and Al-Kindi.

The third grade introduces a further substantive commitment. One may accept the principle that to see, one must look, and yet deny that looking constitutes, even in part, seeing. So, the third grade is a further commitment. But even the three grades taken together are insufficient for a commitment to extramission. Contemporary enactivists, for example, such as Noë (2004), accept something like the first three grades, but enactivism is not a species of extramission.

The fourth grade of extramissive involvement incurs a genuine extramissive element but falls short of a full commitment to the extramission theory. It is only when the outer-directed activity of the perceiver that constitutes, at least in part, their perception of the object is conceived as something spatially extending to the distal object so that it is in contact with that object do we get a genuine extramissive element but one that arguably falls short of a full commitment to a pure form of the extramission theory. (It may be sufficient if the goal of the extramission theory is to provide a mathematically coherent account of vision in the tradition of geometrical optics, but, recall, like Galen and Augustine, we are focusing on physiological and psychological explanations of vision.)

So, consider the following. Francisco Suarez (Comm. una cum quest. in lib. Arist. de anima 3.17.1) marks a distinction between accounts where vision occurs at the point where the ray meets the perceived object and accounts where the object's species must somehow be reflected back to the eye first. Suarez cites Galen, in De Plac. Hipp. et Plat. 7, as attributing the latter kind of account to Plato (see, as well, Theophrastus, De sensibus 1.5 for a similar reading of Plato). The latter accounts, while involving extramissive elements, seem more aptly deemed interactionist, as vision is the result of the interaction of the perceiver's activity and the activity of the object perceived (Smith 1996, 22-23, lerodiakonou 2005, Remes 2014, Squire 2016, and Kalderon 2018, 13). Such accounts not only involve extramissive elements but intromissive elements as well. Moreover, if the species must somehow be reflected back to the eye before vision occurs, then the extramissive activity is merely a precondition for intromission. So, the latter accounts are not purely extramissive. Indeed, they are fundamentally intromissive. The principle governing sensation lies within the perceiver which is why the effect of the perceived object must be transmitted within along the extended ray. Only the former accounts count as purely extramissive. If that is right, then the fourth grade may be accepted without a full commitment to the extramission theory.

Consider, then, the former, purely extramissive, accounts where vision occurs at the point where the ray meets the perceived object. Perception is understood to be at least modeled on, if not a form of, sensation by contact. Its principle is: to be perceptible is to be palpable. It is the fifth and highest grade of extramissive involvement that generates the requirement that at least a part of the perceiver spatially extend to the distal object of perception. The principle governing sensation must be extended along with the ray so that it may be in direct contact with the object perceived. Only in this way could that object be palpable to perception and so perceived. On the latter interactionist accounts, perhaps the effect of the perceived object must reach the principle governing sensation lying within. But the fifth grade requires contact with the perceived objectwhich, in the case of vision, is at a distance from the perceiver-and not merely contact with its 
effect. Again, if something extends from the perceiver so that the effect of the perceived object may be transmitted within, the extramissive element is merely a precondition for intromission. So, it is the fifth and highest grade of extramissive involvement that incurs a full commitment to a pure extramission theory.

Unclarity about the commitments of the extramission theory is aided and abetted, in certain circumstances, by the application of a certain methodological stricture. Some modern commentators have marked a distinction between the psychological and the physiological claims that Augustine makes. Moreover, there is a subsequent tendency to interpret Augustine's commitment to extramission as a physiological claim about vision. So understood, the extramission theory is simply a false causal model of distal perception and may be dismissed as a piece of antiquated physiology.

Allow me to make two observations about this. First, in discussions of the soul in late antiquity, psychological and physiological issues are intertwined, which is not to say confused. Consideration of the psychological is not so easily separated from the physiological. Second, and more fundamentally, there is more to the extramission theory than a false causal model. The extramission theory, in its fifth and highest grade, essentially involves a psychological claim, that the perceived object must be in contact with the principle governing sensation. And the first three grades of extramissive involvement make important claims about the active, outer-directed phenomenology of vision. Thus, the psychologists Winer and Cottrell (1996) hypothesize that the tendency for extramission beliefs to persist into adulthood and their resistance to experimental intervention are partly explained by a phenomenological truth enshrined in extramission models:

We assume that core aspects of the phenomenology of vision underlie extramission interpretations. Consider one phenomenologically salient aspect of vision, namely, its orientational or outer-directed quality. When people see, they are generally oriented toward an external visual referent, that is, they direct their eyes and attention to an object in order to see it. In fact, this quality of vision is reflected in language. People talk about "looking at" things, and English has expressions such as "looking out of a window" and "looking out of binoculars." ... (Winer and Cottrell, 1996, 140)

Notice that the phenomenological grounds that Winer and Cottrell postulate for the persistence of extramission beliefs are enshrined in the first three grades of extramission. It would be a mistake to dismiss the extramission theory merely on the grounds of being an antiquated physiology. The extramission theory essentially involves a principle governing sensation and makes important claims about the phenomenology of vision.

\section{Extramission in the Augustinian Corpus}

In this final section we shall briefly review the strength of evidence for attributing an extramission theory to Augustine on the basis of his other works. At best, it is neither required by scripture nor reason, but is authoritative opinion, and so a defeasible commitment, by Augustine's lights. At times he complains of its subtlety and obscurity, emphasizing its failure to be clearly demonstrated. Many passages involving extramissive elements are, in fact, making a point about something other than perception. And very often this point is independent of the truth of the extramission theory. And sometimes Augustine will pursue his point even when it proves to be in tension with the extramission theory. I conclude that the extramission theory is not a central element in Augustine's thinking about perception. That he was nonetheless persistently drawn to it is explicable. And not just because it was the authoritative opinion of Plato, Ptolemy, and Galen, at least as traditionally understood (we have entertained doubts whether Plato's account is purely extramissive). Rather, perception is the soul's activity using the eye as an instrument. Augustine understands this in a way that only commits him to the first three grades of extramissive involvement. On occasion Augustine flirts with the fourth grade of extramission. Where he does so, he thus abandons or at least brackets his early anti-extramission argument of DQA. If the eye emits a ray that extends to the object see, then it need not have the passive power to be affected 
where it is not. When Augustine seemingly accepts the fourth grade, he does so defeasibly, in deference to authoritative opinion, and he never commits himself to the fifth and highest grade of extramissive involvement. What is central to and persistent in Augustine's thinking about perception is the first three grades of extramissive involvement, but, again, only the fourth involves a genuine extramissive element, and only the fifth incurs a full commitment to a pure form of the extramission theory.

\subsection{De musica}

In De musica, Augustine compares the way in which the activity of memory comprehends the temporally distant to the way in which the activity of sight, as the extramission theory conceives of it, comprehends the spatially distant:

Then, as the diffusion of rays shining out into the open from tiny pupils of the eye, and belonging therefore to our body, in such a way that, although the things we see are placed at a distance, they are yet quickened by the soul, so, just as we are helped by their effusion in comprehending place-spans, the memory too, because it is somehow the light of time-spans, so far comprehends these time-spans as in its own way it too can be projected. (De musica 68 21; Taliaferro 1947, 346)

Augustine's point here is not about perception but memory, that it is somehow the light of timespans that discloses the temporally distant. That point can be made, and made as Augustine does by analogy with the extramission theory of vision, without commitment to the truth of the extramission theory. Indeed, Augustine's doctrine of illumination is more directly relevant to understanding the way in which memory is the light of time-spans that discloses the temporally distant than the extramission theory (on the doctrine of illumination see Allers 1952 and Matthews 2014).

\subsection{De Gen. ad lit.}

In De Gen. ad lit., Augustine provides a phenomenology of focal attention that makes use of extramissive elements:

The shaft of rays from our eyes, to be sure, is a shaft of light. It can be pulled in when we focus on what is near our eyes and sent forth when we fix on objects at a distance. But when it is pulled in, it does not altogether stop seeing distant objects, although, of course, it sees them more obscurely than when it focuses its gaze upon them. Nevertheless, the light which is in the eye, according to authoritative opinion, is so slight that without the help of light from outside we should be able to see nothing. Since, moreover, it cannot be distinguished from the outside light, it is difficult as I have said, to find an analogy by which we might demonstrate the diffusion of light to make the day and a contraction to make the night. (De Gen. ad lit. 1 16; Taylor 1982, 37-38)

The present extramissionist account is derived neither from scripture nor reason, but is accepted as received authoritative opinion. It is potentially revisable in the way that the deliveries of scripture and reason are not. Especially since the authoritative opinion is no mere record of observation. The authoritative opinion includes Plato's explanation, in the Timaeus 45b-c, of the necessity of light for seeing, that the light emitted from the eye must be supplemented by external light in order for the perceiver to see. This has the consequence that the emitted light cannot be distinguished from the external light and so is not directly observable.

A tension in the account raises a potential difficulty. Extramission theories are motivated by an apparent need to be in contact with distant sense objects if the perceiver is to be aware of them. But Augustine explicitly denies this in this passage "when it is pulled in, it does not altogether stop seeing distant objects, although, of course, it sees them more obscurely than 
when it focuses its gaze upon them." The visual ray need not be in contact with the distal object in order to perceive it, but it does so less clearly than if it were. The passage provides a phenomenology of focal attention that seems to conflict with the requirement that the principle of sensation be in contact with the objects of sensory awareness.

The present account is usefully compared to the extramissionist account that Nemesius attributes to the "geometricians" in De natura hominis 7. We get a similar description of the phenomenology of focal attention, also set within an extramissionist account, but where the binocular character of vision is made explicit and exploited in an explanation for how we can see many things all at once. For consider a ray sent from a single eye. It would be natural to expect that it sees only that with which it is in contact. But what we see is not restricted in this way. Reflection on binocular vision provides an explanation. The rays from both eyes form a cone. Where the rays intersect is the point of focal attention where things appear exactly in a way that is meant to be consistent with many other things appearing as well if not exactly. However, even objects outside of the cone are in contact with visual rays emitted from at least one eye. So an extramissionist account of binocular vision would resolve the difficulty raised by the account in $D e$ Gen. ad lit.. However, beyond speaking of the eyes in the plural there is no explicit discussion of binocular vision in that work. And though Augustine's claims about focal attention generated the tension with the pure form of the extramission theory, Augustine does not acknowledge this tension, let alone consider its resolution by means of an extramission theory elaborated to account for binocular vision.

\subsection{Sermon 277}

In $411 \mathrm{CE}$, on the birthday of the martyr Vincent, Augustine delivered the following as part of a sermon:

In this very body, which we carry around with us, I can find something whose inexpressible swiftness astonishes me; the ray from our eye, with which we touch whatever we behold. What you see, after all, is what you touch with the ray from your eye. (Sermon 277 10; Hill 1994, 38)

Augustine is using the familiar tactile metaphor associated with extramission theories. But what is it a metaphor for? Arguably, touch is a metaphor for the presentation in sight of the object of vision. That we touch whatever we behold may be too weak, by itself, to establish that, but it is combined with the claim that what you see is what you touch with the visual ray. On this reading, visual presentation is either reduced to or is at the very least modeled on tactile presentation. If that is right, then Hill $(1994,46 \mathrm{n} .17)$ is wrong to speculate that "presumably on meeting a visible object <the rays > send back the message to the subject...or perhaps they bounce straight back to the eye like radar". Recall Suarez's contrast (section 6) between accounts where vision occurs at the point where the ray meets the perceived object and accounts where the object's species must somehow be reflected back to the eye first. The rays, as Hill conceives of them, are merely part of the causal medium through which information about the perceived object is conveyed. But if the visual rays touch the objects of perception, then they are perceived where they are, and thus there is no need for a signal to return to the subject.

Augustine explains occlusion as the obstruction of visual rays. This could not be an argument for the extramission theory, as occlusion is equally well explained on the intromissionist hypothesis. Rather, the example of a man obscuring a distant column, is setting up the real topic of Sermon 277 10, the "inexpressible swiftness" of the visual rays, which will lead Augustine to an interpretation of Paul's phrase "in the twinkling of an eye" (1 Corinthians 15:52) in Sermon 277 11, understood as the speed at which the body will be resurrected. Like the light of time-spans in $D e$ musica, Augustine's point about the interpretation of the Pauline expression could be made without commitment to the extramission theory.

Augustine speaks of the "inexpressible swiftness" of the visual rays, but strictly speaking, their action is instantaneous. If two objects, one near-a man-and one far-a column-are 
visible to the perceiver, in the circumstances of perception (and hence the man no longer occludes the column), then it is not the case that the visual rays reach the near object sooner than the far:

You don't get to him sooner and to it later; and here he is, nearby, and it's a long way off. If you wanted to walk, you would get to the man sooner than to the column; because you wanted to see, you have got to the column as soon as the man. And yet, as soon as you open your eyes, lo and behold, you yourself are here, your ray is there. As soon as you wanted to see it, you reached it by seeing it. ... Just opening your eyes constitutes reaching it. (Sermon 277 10; Hill 1994, 39)

Notice that the "inexpressible swiftness" of the visual ray is contrasted with the speed of corporeal activities such as walking. Perhaps, like Philoponus, Augustine maintains that instantaneous action at a distance is only possible for incorporeal activity (In Arist. De anima lib. 325.1-341.9). After all, instantaneous action at a distance would require a body to travel at infinite speed, but bodies, no matter how swift, only travel at finite speeds. But if the "inexpressible swiftness" of the visual ray is contrasted with the speed of corporeal activities, the activity of the ray is plausibly spiritual and hence incorporeal. If so, nothing corporeal extends to the perceived object. And if only the corporeal admits of extension, nothing is substantially located where the perceived object is.

Galen's version of the extramission theory addresses this issue in a different way by denying that what travels with "inexpressible swiftness" is a body (thus also resolving some of Aristotle's objections in De sensu 2). But neither is it an incorporeal activity as Philoponus and perhaps Augustine maintain. Rather it is an effect of the emitted pneuma, a quality immediately instantiated by the external light. Like Aristotle, Galen maintains that the external light is already a continuous unity. The "inexpressible swiftness" would consist in the quality being instantiated, all at once, by that continuous unity (De Plac. Hipp. et Plat. 7.4-5). There is no evidence that Augustine entertained, let alone endorsed, the Galenic alternative.

There are, then, two claims to be made about Sermon 277. First, like the De musica passage, the point being made by analogy with the extramission theory is independent of the truth of the extramission theory. Second, since the "inexpressible swiftness" of the visual ray is really instantaneous, the visual ray could only be a spiritual, incorporeal activity, with the result that nothing is substantially located where the perceived object is which is, at the very least, inconsistent with the fifth and highest grade of extramissive involvement.

\subsection{De Trin.}

In De Trin., Augustine writes:

For the mind does not know other minds and not know itself, as the eye of the body sees other eyes and does not see itself; for we see bodies through the eyes of the body, because, unless we are looking into a mirror, we cannot refract and reflect the rays themselves which shine for through the eyes, and touch whatever we discern-a subject, indeed, which is treated of most subtly and obscurely, until it be clearly demonstrated whether the fact be so, or whether it be not. But whatever is the nature of the power by which we discern through the eyes, certainly, whether it be rays or anything else, we cannot discern with the eyes that power itself; but we inquire into it with the mind, and if possible, understand this with the mind. (De Trin. 9 3; Haddan 1873, 226)

Again, the present extramissionist account is derived neither from scripture nor reason. Nor is it, in this instance, even accepted as received authoritative opinion. Notice that Augustine, after having introduced the extramissionist imagery of rays, immediately brackets that commitment, claiming that it is treated subtly and obscurely and claims that the explanation of perceptual 
discernment by rays has not yet been clearly demonstrated. (This reinforces the doubt raised in subsection 7.2 since the composition of De Trin. overlaps the composition of De Gen. ad lit.)

The central point of this passage is independent of the truth of the extramission theory. Moreover, it echoes a Neoplatonic theme. We get a contrast between the activity of the mind and the activity of the animated eye. Whereas the mind is spiritual, the animated eye is a compound of the corporeal and the spiritual. The animated eye is part of the living being, the compound of the organ and the sensitive soul that animates that organ and uses it as an instrument for the soul's activities. The mind may apprehend itself in thought in the way that the power of sight acting through the eye could not apprehend itself in vision. In Neoplatonic vocabulary, the mind's activity, being purely spiritual, is capable of reverting upon itself the way that the visual activity of the animated eye, being a compound of the corporeal and the spiritual, could not (compare Proclus' demonstration of proposition 15 of Element. Theol.: "All that is capable of reverting upon itself is incorporeal" and Aquinas 'Super Lib. de Causis exp. propositions 7 and 15). Augustine's point about the failure of sight's activity to revert upon itself does not depend upon the truth of extramission. Augustine's point is, in that sense, independent of the truth of the extramission theory.

\section{Conclusion}

The extramission theory is not a central element in Augustine's thinking about perception. That he was nonetheless persistently drawn to it is explicable. And not just because it was the authoritative opinion of Plato, Ptolemy, and Galen, at least as traditionally understood. Rather, perception is the soul's activity using the eye as an instrument. Perception is not something done to the perceiver, it is the soul, through the use of the body, that perceives. Sensory awareness is an activity of the soul within the soul itself. According to Augustine, vision involves outer-directed, rectilinear activity that constitutes the perception of the object. Augustine is committed to the first three grades of extramissive involvement. But a genuine extramissive element only occurs in fourth grade of extramissive involvement, and a full commitment to a pure form of extramission is only incurred with the acceptance of the fifth and highest grade. And in DQA at least, Augustine is committed to the rejection of the fourth and fifth grades.

Department of Philosophy

University College London

Gower Street

London WC1E 6BT

\section{Bibliography}

Alexander of Aphrodisias. De anima in M. Bergeron and R. Dufour (ed.) Alexander Aphrodisiensis. De l'âme. Texte grec introduit, traduit et annoté (Paris: Vrin, 2008).

Rudolph Allers. "St Augustine's doctrine on illumination," Franciscan Studies, 12(1): 27-46, March 1952.

Thomas Aquinas. Super Librum de Causis expositio, H.D. Saffrey (ed.) (Éditions E. Nauwelaerts, 1954).

Aristotle. De anima in Paul Siweck (ed.) Tractatus De Anima, Graece et Latine. (Rome: Desclée \& Ci., 1965).

Aristotle. De sensu in Paul Siweck (ed.) Aristotelis Parva naturalia, Graece et Latine (Rome:

Desclée \& Ci., 1963).

Aurelius Augustinus Hipponensis. Confessiones in P. Knöll (ed.) Corpus scriptorum ecclesiasticorum Latinorum, volume 33 (Prague, Vienna, and Leipzig: F. Tempsky, 1896).

Aurelius Augustinus Hipponensis. De Genesi ad litteram libri duodecim in J. Zycha (ed.) Corpus scriptorum ecclesiasticorum Latinorum, volume 28 (Vienna and Prague: F. Tempsky, 1894). Aurelius Augustinus Hipponensis. De magistro in G. Weigel (ed.) Corpus scriptorum ecclesiasticorum Latinorum, volume 77 (Vienna: Hoelder-Pichler-Tempsky, 1961). 
Aurelius Augustinus Hipponensis. De musica in M. Jacobsson (ed.) Corpus scriptorum ecclesiasticorum Latinorum, volume 102 (Berlin and Boston: De Gruyter, 2017).

Aurelius Augustinus Hipponensis. De quantitate animae in W. Hörmann (ed.) Corpus scriptorum ecclesiasticorum Latinorum, volume 89. (Vienna: Verlag der österreiachen Akademie der Wissenschaften, 1986).

Aurelius Augustinus Hipponensis. Sermon 277 in Jacques-Paul Migne (ed.) Patrologia Latina, volume 38 (Paris: Garnier Fratres, 1863).

Aurelius Augustinus Hipponensis. De Trinitate in W.J. Mountain (ed.) Corpus Christianorum Series Latina, volume 50 (Turnhout: Brepolis, 1968).

Roger Bacon. Perspectiva in David C. Lindberg (ed. and trans.) Roger Bacon and the Origins of Perspectiva in the Middle Ages, A Critical Edition and English Translation of Bacon's Perspectiva with Introduction and Notes (Oxford: Clarendon Press, 1996).

Vernon J. Bourke. Augustine's Quest of Wisdom (Milwaukee: The Bruce Publishing Company, 1947).

Charles Brittain. "Non-rational perception in the Stoics and Augustine," Oxford Studies in Ancient Philosophy, 22:253-308, Summer 2002.

Charles Brittain. "Colloquium 7: Attention deficit in Plotinus and Augustine: Psychological problems in Christian and Platonist theories of the grades of virtue," Proceedings of the Boston Area Colloquium of Ancient Philosophy, 18(1):223-275, 2003.

C.D. Broad. "Some elementary reflections on sense-perception," Philosophy, 27(100): 3-17, January 1952. Reprinted in Broad 1965.

C.D. Broad. "Some elementary reflections on sense-perception," in Robert J. Swartz (ed.), Perceiving, Sensing, and Knowing, pages 29-48. (Garden City: Anchor Books, Doubleday \& Company, Inc.,1965).

Deborah Brown. "Agency and attention in Malebranche's theory of cognition," in Martin Pickavé and Lisa Shapiro (ed.), Emotion and Cognitive Life in Medieval and Early Modern Philosophy (Oxford: Oxford University Press, 2012), 217-33.

Harry Edwin Burton. "The optics of Euclid," Journal of the Optical Society of America, 35(5):35772, May 1943.

Sarah Catherine Byers. Perception, Sensibility, and Moral Motivation in Augustine, A StoicPlatonic Synthesis (Cambridge: Cambridge University Press, 2013).

Cleomedes. Meteōra in Robert B. Todd (ed.) Cleomedis Caelestia (Meteora) in Bibliotheca scriptorum Graecorum et Romanorum Teubneriana (Berlin and Boston: De Gruyter, 1990). Joseph M. Colleran. St Augustine, The Greatness of the Soul, The Teacher, volume 9 of Ancient Christian Writers, The Works of the Fathers in Translation. (New York and Mahwah: The Newman Press, 1949).

Daniel C. Dennett. Consciousness explained, Penguin Science, (Penguin, 1993).

René Descartes. Discours de la methode pour bien conduire sa raison, chercher la verité dans les sciences: plus la dioptrique, les meteores, et la geometrie, qui sont des essais de cete methode (Leiden: Jan Maire, 1637).

H. Diels and W. Kranz. Die Fragmente der Vorsokratiker (DK), 6th edition, (Berlin: Weidmann, 1974).

Blake D. Dutton. "The objection from touch: Sensation, extension and the soul in Augustine's The Quantity of the Soul," History of Philosophy and Logical Analysis, 1-28, 2020.

Epicurus. Letter to Herodotus in Miroslav Marcovich (ed.) Diogenis Laertii Vitae philosophorum in Bibliotheca scriptorum Graecorum et Romanorum Teubneriana (Stuttgart: Teubner, 1999-2002).

Euclid. Optics in J.L. Heiberg (ed.) Euclidis Opera Omnia, volume 7 (Leipzig: Teubner, 1895).

Claudius Galenus. De placitis Hippocratis et Platonis in Phillip De Lacy (ed. and trans.) Galen On the Doctrines of Hippocrates and Plato, Second Part: Books VI- IX, Corpus Medicorum

Graecorum. (Berlin: Akademie-Verlag, 1980).

Sister Mary Ann Ida Gannon. "The active theory of sensation in St. Augustine," New

Scholasticism, 30(2):154-180, 1956.

Etienne Gilson. The Christian Philosophy of Saint Augustine, translated by L.E.M. Lynch (London: Victor Gollancz LTD, 1961). 
Vincent A. Guagliardo, Charles R. Hess, and Richard C. Taylor. St. Thomas Aquinas, Commentary on the Book of Causes, Thomas Aquinas in Translation (Washington: Catholic University of America Press, 1996).

Arthur West Haddan. On the Trinity, volume 7 of The Works of Aurelius Augustine, Bishop of Hippo, A New Translation (Edinburgh: T. \& T. Clark, 35 George Street, 1873).

Edmund Hill. Sermons in The Works of Saint Augustine, A Translation for the 21st Century, Part III (Hyde Park: New City Press, 1994).

Katerina lerodiakonou. "Plato's theory of colours in the Timaeus," Rhizai. A Journal for Ancient Philosophy of Science, (2):219-233, 2005.

Brad Inwood. The Poem of Empedocles, A Text and Translation with an Introduction (Toronto: University of Toronto Press, 2001).

Mark Eli Kalderon. Form without Matter, Empedocles and Aristotle on Color Perception (Oxford: Oxford University Press, 2015).

Mark Eli Kalderon. Sympathy in Perception (Cambridge: Cambridge University Press, 2018).

Edward N. Lee. "The sense of an object: Epicurus on seeing and hearing," in Peter K. Machamer and Robert G. Turnbull (ed.), Studies in Perception, Interrelations in the History of Philosophy and Science (Columbus: Ohio State University Press, 1978), 27-59.

David C. Lindberg. Theories of Vision from al-Kindī to Kepler (Chicago: Chicago University Press, 1977).

David C. Lindberg. "The intromission-extramission controversy in Islamic visual theory: Alkindi versus Avicenna," in Peter K. Machamer and Robert G. Turnbull (ed.), Studies in Perception, Interrelations in the History of Philosophy and Science (Columbus: Ohio State University Press, 1978), 137-159.

Luckás Lickka. "The visual process: Immediate or successive? Approaches to the extramission postulate in 13th century theories of vision," in Elena Băltuţă (ed.), Medieval Perceptual Puzzles, Theories of Sense Perception in the 13th and 14th Centuries, volume 13 of Investigating Medieval Philosophy (Brill, 2020), 73-110.

Gareth B. Matthews. "Knowledge and illumination," in David Vincent Meconi and Eleonore Stump (ed.), The Cambridge Companion to Augustine (Cambridge: Cambridge University Press, 2014), 171-185.

John J. McMahon. The magnitude of the soul (De quantitate animae), in The Immortality of the Soul; The Magnitude of the Soul; On Music; The Advantage of Believing; On the Faith in Things Unseen, volume 4 of The Fathers of the Church (Catholic University of America Press, 1947). Maurice Merleau-Ponty. The Structure of Behavior (Boston: Beacon Press, 1967).

Nemesius. De natura homonis in R.W. Sharples and P.J. van der Eijk (trans.) Nemesius: On the Nature of Man (Liverpool: Liverpool University Press, 2008).

Alva Noë. Action in Perception (Cambridge: MIT Press, 2004).

Gerard O'Daly. Augustine's Philosophy of Mind (Berkeley and Los Angeles: University of California Press, 1987).

Peter John Olivi. Quaestiones in secundum librum Sententiarum, volumes 1-3. Bernard Jansen (ed.) (Firenze: Collegium S. Bonaventurae, 1922-6).

Philoponus. In Aristotelis De anima libros in Michael Hayduck (ed.) Commentaria in Aristotelem Graeca, in Aristotelis de anima libros commentaria, volume 15 (Paris: Berolini, 1897).

Plato. First Alcibiades in J. Burnet (ed.) Platonis Opera, volume 2 (Oxford: Oxford University Press, 1901).

Plato. Sophistes in E.A. Duke, W.F. Hicken, W.S.M. Nicoll, D.B. Robinson, and J.C.G. Strachan. Platonis Opera, volume 1 (Oxford: Oxford University Press, 1995).

Plato. Theaetetus in E.A. Duke, W.F. Hicken, W.S.M. Nicoll, D.B. Robinson, and J.C.G. Strachan. Platonis Opera, volume 1 (Oxford: Oxford University Press, 1995).

Plato. Timaeus in J. Burnet (ed.) Platonis Opera, volume 4 (Oxford: Oxford University Press, 1905). Plotinus. Enneads in P. Henry and H.R. Schwyzer (ed.) Plotini Opera, volumes 1-3 (Oxford:

Clarendon Press,1964-1984).

Porphyry. Ad Gaurum in Karl Kalbfleisch (ed.) Die neuplatonische, fälschlich dem Galen zugeschriebene Schrift Pros Gauron peri tou pôs empsukhoutai ta embrua. Aus dem Anhang zu 
den Abhandlungen der Königl (Berlin: Abhandlungen der Preussischen Akadamie der Wissenschaft, 1895).

Priscian of Lydia. Metaphrasis in Theophrastum in I. Bywater. Supplementum Aristotelicum Voluminis I Pars II Priciani Lydi Quae Extant (Paris: G. Reimer, 1886).

Proclus. Elementatio Theologica in E.R. Dodds. Proclus, The Elements of Theology, 2nd edition, (Oxford: Clarendon Press, 1963).

W. V. Quine. "Three grades of modal involvement," Proceedings of the XIth International Congress of Philosophy, 14:65-81, 1953.

Paulina Remes. "Plato: Interaction between the external body and the perceiver in the Timaeus," in José Filipe Silva and Mikko Yrjönsuuri (ed.) Active Perception in the History of Philosophy, volume 14 of Studies in the History of Philosophy of Mind (Springer, 2014).

John Sellars. "Augustine and the stoic tradition," In The Oxford Guide to the Historical Reception of Augustine, volume 3 (Oxford: Oxford University Press, 2013), 1775-79.

José Filipe Silva. "Augustine on active perception" in José Filipe Silva and Mikko Yrjönsuuri, (ed.) Active Perception in the History of Philosophy, From Plato to Modern Philosophy, volume 14 of Studies in the History of Philosophy of Mind (Cham, Heidelberg, New York, Dordrecht, and London: Springer, 2014), 79-98.

José Filipe Silva and Juhana Toivanen. "The active nature of the soul in sense perception: Robert Kilwardby and Peter Olivi," Vivarium, 48(3):245-278, 2010.

A. Mark Smith. Ptolemy's Theory of Visual Perception, An English Translation of the Optics with Introduction and Commentary, volume 86, part 2 of Transactions of the American Philosophical Society held at Philadelphia for Promoting useful Knowledge (Philadelphia: The American Philosophical Society, 1996).

A. Mark Smith. From Sight to Light, The Passage from Ancient to Modern Optics. (Chicago and London: The University of Chicago Press, 2015).

Richard Sorabji, Pamela Huby, Carlos Steel, and Peter Lautner. Priscian: On Theophrastus On Sense Perception with Simplicius : On Aristotle on the Soul 2.5-12 of Ancient Commentators on Aristotle (London, New Delhi, New York, and Sydney: Bloomsbury, 1997).

Michael Squire. "Introductory reflections, making sense of ancient sight," in Michael Squire (ed.) Sight and the Ancient Senses, The Senses in Antiquity (London and New York: Routledge, Taylor \& Francis Group, 2016), 1-35.

Francisco Suarez. Commentaria una cum questionibus in libros Aristotelis De anima in Salvador Castellote (ed.) Comentarios a los Libros de Aristóteles Sobre El Alma, volumes 1-3 (Madrid: Sociedad de Estudios y Publicaciones, 1978-92).

Peter Sutton. Quodlibeta in Ferdinand Etzkorn (ed.) "Petrus Sutton(?) O.F.M., Quodlibeta," Franciscan Studies, 23: 68-139, 1963.

Robert Catesby Taliaferro. The Immortality of the Soul; The Magnitude of the Soul; On Music; The Advantage of Believing; On the Faith in Things Unseen, volume 4 of The Fathers of the Church (Washington: Catholic University of America Press, 1947).

John Hammond Taylor. St Augustine, The Literal Meaning of Genesis (New York and Mahwah: Paulist Press, 1982).

Theophrastus. De sensibus in George Malcolm Stratton (trans.) Theophrastus and the Greek Physiological Psychology before Aristotle (New York: The Macmillan Company, 1917).

Tideus. De speculis in Axel Anton Bjømbo and Sebastian Vogel (ed.) Alkindi, Tideus und PseudoEuklid: drei optische Werke (Leipzig and Berlin: Teubner, 1912).

Juhana Toivanen. Perception and the Internal Senses, Peter of John Olivi on the Cognitive Functions of the Soul, volume 5 of Investigating Medieval Philosophy (Leiden and Boston: Brill, 2013).

Francis E. Tourscher. Saint Augustine, De Quantitate Animae, The Measure of the Soul, Latin Text with English Translation and Notes (London: The Peter Reilly Company, 1933).

Robert G. Turnbull. "The role of the 'special sensibles' in the perception theories of Plato and Aristotle," in Peter K. Machamer and Robert G. Turnbull (ed.) Studies in Perception, Interrelations in the History of Philosophy and Science (Columbus: Ohio State University Press, 1978), 3-26. Gerald A. Winer and Jane E. Cottrell. "Does anything leave the eye when we see? Extramission beliefs of children and adults," Current Directions in Psychological Science, 5(5):137-142, 1996. 
M. R. Wright. Empedocles: The Extant Fragments, Edited with an Introduction, Commentary, Concordance (New Haven: Yale University Press, 1981). 